\title{
REVIEW
}

\section{Consequences of a compromised intrauterine environment on islet function}

\author{
Alice S Green, Paul J Rozance ${ }^{\mathbf{1}}$ and Sean W Limesand \\ Department of Animal Sciences, University of Arizona, 1650 East Limberlost Drive, Tucson, Arizona 85719, USA \\ ${ }^{1}$ Department of Pediatrics, University of Colorado, Denver, Colorado 80045, USA \\ (Correspondence should be addressed to S W Limesand; Email: limesand@ag.arizona.edu)
}

\begin{abstract}
Low birth weight is an important risk factor for impaired glucose tolerance and diabetes later in life. One hypothesis is that fetal $\beta$-cells inherit a persistent defect as a developmental response to fetal malnutrition, a primary cause of intrauterine growth restriction (IUGR). Our understanding of fetal programing events in the human endocrine pancreas is limited, but several animal models of IUGR extend our knowledge of developmental programing in $\beta$-cells. Pathological outcomes such as $\beta$-cell dysfunction, impaired glucose tolerance, and diabetes are often observed in adult offspring from these animal models, similar to the associations of low birth weight and metabolic diseases in humans. However, the identified mechanisms underlying $\beta$-cell dysfunction across
\end{abstract}

models and species are varied, likely resulting from the different methodologies used to induce experimental IUGR, as well as from intraspecies differences in pancreas development. In this review, we first present the evidence for human $\beta$-cell dysfunction being associated with low birth weight or IUGR. We then evaluate relevant animal models of IUGR, focusing on the strengths of each, in order to define critical periods and types of nutrient deficiencies that can lead to impaired $\beta$-cell function. These findings frame our current knowledge of $\beta$-cell developmental programing and highlight future research directions to clarify the mechanisms of $\beta$-cell dysfunction for human IUGR.

Journal of Endocrinology (2010) 205, 211-224

\section{Introduction}

The incidence of type 2 diabetes mellitus (T2DM) is growing worldwide. It is now well established that interactions between an individual's genetic makeup and environment contribute to the development of T2DM (Gerich 1998). Evidence continues to mount showing that T2DM is more prevalent among subjects that were intrauterine growth restricted (IUGR) during fetal development, indicating that the defects in glucose homeostasis originate in utero (Barker et al. 1993, Ravelli et al. 1998, Newsome et al. 2003). The reciprocal relationship between insulin secretion and sensitivity (Table 1) suggests that defects occur in either insulin secretion capacity or insulin action at target tissues, or both in the case of T2DM (Robertson 1992, Kahn et al. 1993, Weir 1993a,b). Despite differences in the type, timing, and duration of intrauterine insult, most animal models of IUGR have similar outcomes of impaired glucose tolerance or T2DM. However, because the etiology of these phenotypes can involve a variety of mechanisms, they are relatively nonspecific endpoints. Therefore, care is required when interpreting animal studies and planning interventions to ameliorate $\beta$-cell dysfunction. In this review, we discuss the evidence for $\beta$-cell dysfunction in human IUGR and identify several potential mechanisms found in animal models that begin to explain these outcomes.

\section{$\beta$-Cell defects in small-for-gestational-age-infants}

Human studies generally compare outcomes in small-forgestational-age-neonates (SGA; usually defined as $<10$ th percentile for birth weight, although the statistical cut-off can vary) to appropriate-for-gestational-age-neonates (AGA). Although birth weight is the most accessible proxy for fetal growth restriction, the statistical nature of this classification may introduce heterogeneity into human studies, whereas the term IUGR describes a pathophysiological process. In most cases, IUGR occurs in genetically normal fetuses that are restrained from reaching their full growth potential. This is usually associated with placental insufficiency and almost always with fetal undernutrition, which causes asymmetric fetal growth (Platz \& Newman 2008). IUGR is rarely diagnosed before $22-24$ weeks of gestation, but detection is 
Table 1 Measurements of glucose metabolism and insulin secretion

Definition

Term

Insulin secretion

Insulin sensitivity

Insulin resistance

Insulin disposition

Impaired glucose tolerance
Capacity of $\beta$-cells to release insulin in response to a secretagogue

Capacity of insulin-responsive tissues (i.e. muscle, adipose, and liver) to extract glucose from circulation at a given insulin concentration

A condition in which responsive tissues do not respond adequately to normal amounts of insulin

An index that includes measurements for both insulin secretion and insulin sensitivity in order to assess $\beta$-cell function

Prediabetic state that is demonstrated by an inability to clear glucose or slowed return to glucose homeostasis after administration (glucose disposal)

Affected by both insulin secretion and insulin sensitivity
Test

Glucose-stimulated insulin secretion (GSIS) - insulin response to an i.v. glucose infusion Intravenous arginine stimulation tests (IVAST) insulin response to an i.v. arginine bolus Glucose-potentiated arginine-induced insulin secretion (GPAIS) - insulin response to a continuous i.v. glucose infusion followed by an i.v. arginine bolus

Hyperinsulinemic-euglycemic clamp (HEC) insulin concentration is raised with a constant infusion, and glucose is adjusted to maintain euglycemia

Intravenous glucose tolerance tests (IVGTT) measure clearance of a glucose bolus

Homeostatic model assessment (HOMA) or quantitative insulin sensitivity check index (QUICKI) - estimates insulin resistance by fasting insulin and glucose concentrations

Calculated as insulin responsiveness (e.g. $\mathrm{AUC}_{\text {insulin }}$ / $A \cup C_{\text {glucose }}$ during OGTT) multiplied by an insulin sensitivity index

Oral glucose tolerance test (OGTT) or intravenous glucose tolerance tests (IVGTT) - glucose disposal after the administration of glucose bolus. IVGTT can also be used to measure first-phase insulin secretion improving with increasing use of ultrasonography (Ferrazzi et al. 2002, Creasy et al. 2004). Despite the limitations of the SGA classification, the human studies discussed below provide substantial evidence for relationships between birth weight and metabolic syndromes resulting from $\beta$-cell dysfunction.

Based on umbilical cord blood sampling, SGA fetuses have lowered blood oxygen levels; decreased plasma amino acids, glucose, and insulin (Economides et al. 1989, Setia et al. 2006); and increased catecholamine concentrations (Greenough et al. 1990) relative to AGA controls. Glucose-stimulated insulin secretion (GSIS; Table 1) has been measured in IUGR fetuses (diagnosed by ultrasound) prior to the onset of labor or maternal anesthesia. They demonstrated an almost complete absence of first-phase insulin secretion compared with a robust response in control fetuses (Table 2; Nicolini et al. 1990). Elucidation of the mechanisms responsible for impaired GSIS in IUGR fetuses has been limited to measurements of pancreatic morphology. One study found no differences in the $\beta$-cell population between SGA $(<10$ th percentile) and AGA fetuses (50-75th percentiles) at 36 weeks of gestation (Beringue et al. 2002). However, newborns with severe SGA ( $<3$ rd percentile) had a lower fraction of $\beta$-cells and smaller islets with less pronounced vasculature than AGA newborns $(\sim 40$ th percentile $)$ at $\sim 34$ weeks of gestation (Van Assche et al. 1977). Together, these studies demonstrate that, at least in severe IUGR fetuses, the pancreatic $\beta$-cell population and insulin secretion are reduced (Table 2).

In the literature, there are conflicting reports describing neonatal insulin secretion in SGA subjects, spanning from $\beta$-cell dysfunction to overcompensation. One report has shown that $\beta$-cell dysfunction persists in SGA infants at $48 \mathrm{~h}$, but they also tend to be more sensitive to insulin, which may mask impaired glucose tolerance (Bazaes et al. 2003). The relationship between insulin secretion and insulin sensitivity is hyperbolic in nature. Thus, for a given degree of glucose tolerance, the product of insulin secretion and insulin sensitivity is constant, and the changes are reciprocal (i.e. insulin secretion decreases in response to greater insulin sensitivity; Kahn et al. 1993). Therefore, it is important to account for insulin sensitivity when measuring insulin secretion. Another report found that by $72 \mathrm{~h}$, SGA infants had greater plasma insulin concentrations compared with AGA infants, but glucose concentration was not different (Wang et al. 2007). In this study, SGA subjects were not as growth restricted as those examined in the 48-h study, making direct comparisons difficult, but also suggesting a trend for degrees of IUGR. Several case series identify SGA newborns presenting with hyperinsulinemic hypoglycemia (HG). Although retrospective and selective, these cases support $\beta$-cell overcompensation in some SGA newborns (Collins \& Leonard 1984, Collins et al. 1990, Hoe et al. 2006). 


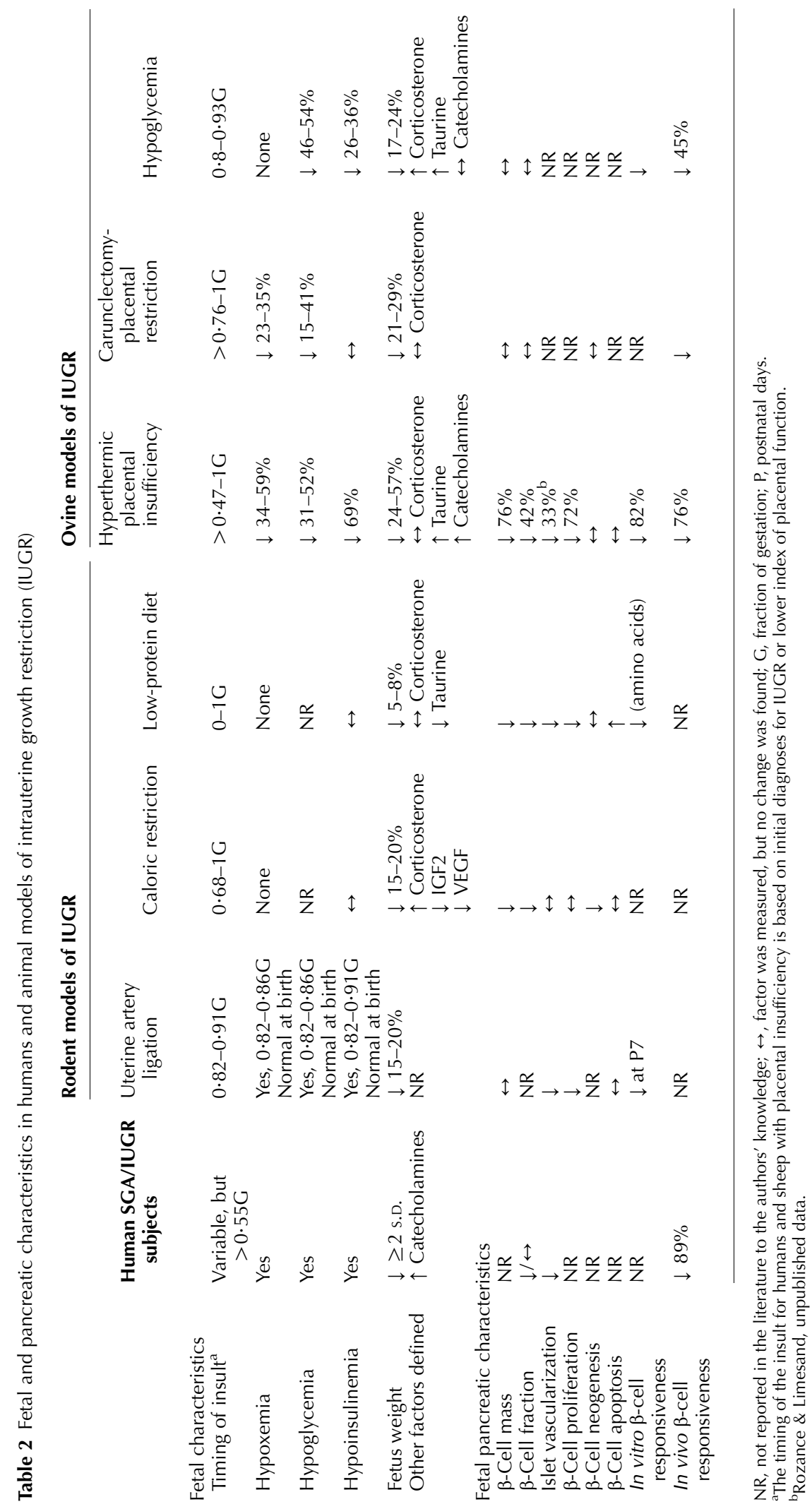


More thorough evaluation is required to determine which infants have persistent $\beta$-cell dysfunction and which develop hyperresponsive $\beta$-cells, as well as to the underlying mechanisms responsible for these differences.

Many SGA children exhibit catch-up growth and reach normal height and weight by 3 years of age (Colle et al. 1976, Bazaes et al. 2004, Iniguez et al. 2006). Those showing catchup growth, especially for length, have greater insulin secretion compared with those without catch-up growth (Colle et al. 1976, Hofman et al. 1997, Crowther et al. 2000, Soto et al. 2003, Bazaes et al. 2004). Catch-up growth is also associated with increased adiposity, raising the incidence of insulin resistance by the time the children reach 5 years of age (Hofman et al. 1997, Ong et al. 2000). This places a greater burden on a $\beta$-cell population already compromised by fetal malnutrition, perhaps accelerating the progression towards $\beta$-cell failure (Mericq et al. 2005).

In SGA children and young adults, reports of insulin secretion and $\beta$-cell function are discordant. Interpretation of results is complicated by the development of insulin resistance (Hofman et al. 1997, Soto et al. 2003, Bazaes et al. 2004, Mericq et al. 2005), in addition to subject population heterogeneity, and confounding environmental variables (e.g. diet and exercise). Even with these limitations, studies that have measured insulin secretion and accounted for insulin sensitivity have shown that insulin secretion is impaired in SGA subjects as children (up to 14 years of age; Li et al. 2001) and in otherwise healthy, glucose-tolerant, 19-year-old men without a family history of diabetes (Jensen et al. 2002). These studies contrast to several reports indicating that $\beta$-cell function was unaffected (Crowther et al. 2000, Flanagan et al. 2000, Soto et al. 2003, Veening et al. 2003). However, these negative studies did not measure insulin sensitivity. Therefore, $\beta$-cell dysfunction relative to insulin resistance is apparent, and over time, these factors combine to cause T2DM in adults born with SGA.

\section{Critical windows for fetal islet development}

Before comparing and contrasting islet deficiencies in animal models of IUGR, we must first consider the timing of events of pancreas morphogenesis and differentiation of endocrine cells. Pancreas development could be impacted differently depending on the timing and duration of restricted nutrition relative to the stage of development. For example, when rat dams are calorie restricted during gestation and lactation, pup $\beta$-cell mass and function are reduced, but this reduction is less severe if the dam is fed adequate calories during lactation. Such postnatal interventions may impact outcomes more markedly in altricial species such as the rat, which undergo extensive islet maturation after birth, compared with precocial species, such as the human and the sheep. Moreover, in rodents, pancreas development appears to happen in discrete transitions, which allows us to dissect out stage-specific complications and relate them to the multifocal developmental progression found in the human and sheep pancreas (Table 3; Sarkar et al. 2008, Cole et al. 2009).

Organogenesis of the pancreas is a highly coordinated process with structural and cytological aspects. Early morphological events of pancreas formation appear to be phylogenetically conserved among mammals (Pictet et al. 1972a). The developmental process begins when the endoderm is specified to 'the pancreatic state', and after the primary transition, these protodifferentiated cells expand to form the pancreatic anlagen (Pictet et al. 1972a). The pancreas originates from the dorsal and ventral region of the foregut endoderm at embryonic day (E) 9.5 in the mouse, E11 in the rat, and 25-26 days gestational age (dGA) in the human (Wessells \& Cohen 1967, Pictet et al. 1972a,b, Piper et al. 2004). Pancreatic precursor cells expand, forming a dense outgrowth that begins to lobulate and then elongates into branches (Rutter 1980, Jensen 2004, Piper et al. 2004, Cole et al. 2009). In rodents, the elongation is associated with a condensed mesodermal covering (Wessells \& Cohen 1967). In contrast, human and sheep pancreatic buds appear to elongate into a loose mesenchymal bed, which occurs between 26 and 41 dGA in the human (Piper et al. 2004) and between 24 and 29 dGA in the sheep (Cole et al. 2009). Reasons for these morphological differences are undefined, but we expect that the mesenchymal cells provide factors to support pancreas development in all mammals (Wessells \& Cohen 1967, Bhushan et al. 2001, Norgaard et al. 2003). Finally, the progenitor cell expansion culminates with the

Table 3 Species comparison of critical periods for pancreas development

\begin{tabular}{|c|c|c|c|c|}
\hline & Mouse & Rat & Sheep & Human \\
\hline Primary transition & $\begin{array}{l}\text { E9.5 } \\
(0 \cdot 5 \mathrm{G})\end{array}$ & $\begin{array}{l}\text { E11 } \\
(0 \cdot 5 \mathrm{G})\end{array}$ & $\begin{array}{l}<24 \mathrm{dGA} \\
(<0 \cdot 16 \mathrm{G})\end{array}$ & $\begin{array}{l}25-26 \mathrm{dGA} \\
(0 \cdot 09 \mathrm{G})\end{array}$ \\
\hline Secondary transition & $\begin{array}{l}\mathrm{E} 13 \cdot 5-\mathrm{E} 15 \cdot 5 \\
(0 \cdot 71-0 \cdot 82 \mathrm{G})\end{array}$ & $\begin{array}{l}\text { E15-18 } \\
(0 \cdot 68-0 \cdot 82 G)\end{array}$ & $\begin{array}{l}24-147 \mathrm{dGA} \\
(0 \cdot 16-1 \cdot 0 \mathrm{G})\end{array}$ & $\begin{array}{l}7 \cdot 5-40 \text { wGA } \\
(0 \cdot 19-1 \cdot 0 G)\end{array}$ \\
\hline Isletogenesis & $\begin{array}{l}\text { E15-19 } \\
(0 \cdot 79-1 \cdot 0 G)\end{array}$ & $\begin{array}{l}\text { E17-21 } \\
(0 \cdot 77-0 \cdot 95 \mathrm{G})\end{array}$ & $\begin{array}{l}33-147 \text { dGA } \\
(0 \cdot 22-1 \cdot 0 G)\end{array}$ & $\begin{array}{l}1-40 \text { wGA } \\
(0 \cdot 28-1 \cdot 0 G)\end{array}$ \\
\hline Endocrine cell proliferation & $\begin{array}{l}\text { E18.5-P30 } \\
(0 \cdot 97-1 \cdot 0 G)\end{array}$ & $\begin{array}{l}\text { E21.5-22 } \\
(0 \cdot 97-1 \cdot 0 \mathrm{G})\end{array}$ & $\begin{array}{l}33-147 \text { dGA } \\
(0 \cdot 22-1 \cdot 0 G)\end{array}$ & $\begin{array}{l}8-40 \text { wGA } \\
(0 \cdot 20-1 \cdot 0 G)\end{array}$ \\
\hline Term gestation & E19 & E22 & $147 \mathrm{dGA}$ & 40 wGA \\
\hline
\end{tabular}

E, embryonic day; dGA, days gestational age; wGA, weeks gestational age; $\mathrm{G}$, fraction of gestation. 
secondary transition 'differentiated state' when mature secretory products are identified, occurring between E13.5 and 15.5 in the mouse and between E15 and 18 in the rat (Wessells \& Cohen 1967, Pictet et al. 1972b). The secondary transition begins before $24 \mathrm{dGA}$ in the sheep and at $52 \mathrm{dGA}$ in the humans, and it proceeds in conjunction with progenitor cell expansion, but defined endpoints are not evident during gestation in either species (Polak et al. 2000, Piper et al. 2004, Cole et al. 2007, 2009).

Studies using genetically engineered mice have defined a hierarchy of transcription factors that coordinates pancreas organogenesis and endocrine cell specification from pluripotent progenitors (for a comprehensive review see Jensen (2004)). For brevity, we will only focus on transcription factors that have also been examined in humans and sheep. A homeodomain protein, pancreatic and duodenal homeobox-1 (PDX1), initiates differentiation and morphogenesis of the pancreatic epithelial progenitor cells and later becomes restricted to mature $\beta$-cells, where it is involved in transactivation of $\beta$-cell-specific genes (Offield et al. 1996, Sander \& German 1997). In humans and sheep, a similar pattern of cellular expression of PDX1 is apparent (Piper et al. 2004, Cole et al. 2009). At the secondary transition in mice, neurogenin 3 (Ngn3 also known as Neurog3) is essential for committing pancreatic epithelial progenitor cells to an endocrine cell lineage (Gradwohl et al. 2000, Jensen et al. 2000). In humans, however, evidence for an absolute requirement of NGN3 is unclear (del Bosque-Plata et al. 2001, Wang et al. 2006). Despite this, the temporal and spatial expression of NGN3 indicates that it is involved in endocrine cell specification in humans and sheep (Sugiyama et al. 2007, Sarkar et al. 2008, Cole et al. 2009).

Two other processes that occur during pancreagenesis include the onset of mature islet cell replication and isletogenesis, both of which also exhibit temporal differences among species. In rodents, the newly formed endocrine cells are mitotically quiescent until near term (E19 mouse and E21.5 rats; Pictet et al. $1972 b$, Jensen et al. 2000, Sander et al. 2000 ), whereas human $\beta$-cells begin to proliferate at 8 weeks gestational age, albeit at low levels, and continue replicating throughout gestation (Bouwens et al. 1997, BocianSobkowska et al. 1999, Kassem et al. 2000, Polak et al. 2000). A similar time frame of onset and duration is found in sheep (Limesand et al. 2005, Cole et al. 2007). The formation of islet-like structures also happens earlier in humans and sheep than in rodents. In humans and sheep, aggregates begin forming shortly after the onset of differentiation, resulting in primitive islets by week 11 in humans (Bocian-Sobkowska et al. 1999, Nieto 2002, Piper et al. 2004) and 33 dGA in sheep (Cole et al. 2009). In contrast, islets do not form until 0.78 of gestation in rodents (Slack 1995, Jensen et al. 2000). During isletogenesis, vascularization of the islets is also observed (Pictet et al. 1972b), and recent findings indicate that endothelial cells augment $\beta$-cell proliferation (Lammert et al. 2001, Nikolova et al. 2006).
In the human fetus, $\beta$-cells exhibit robust insulin secretion in response to insulin secretagogues (Adam et al. 1969, Nicolini et al. 1990). In rats, $\beta$-cells begin to be responsive near term, but the response is not robust until a week after birth (Kervran et al. 1979, Kervran \& Randon 1980). In the sheep fetus, $\beta$-cells respond to glucose and arginine as early as mid-gestation, and the response improves toward term (Molina et al. 1993, Aldoretta et al. 1998). Strikingly, newborn lambs have a GSIS response that is almost 5 times that of the late-term fetus (Philipps et al. 1978). This enhanced GSIS occurs within $6 \mathrm{~h}$ of parturition, suggesting that the changes are induced by the postnatal internal milieu, not by a sudden $\beta$-cell expansion; GSIS potentiation has not been confirmed in human infants.

Morphological and cytological processes for pancreas development appear to be conserved among humans and species that are commonly used as models for IUGR. However, the timing and progression of pancreas development are different in precocious species compared with rodents (Table 3). The distinct developmental transitions observed in rats later in gestation provide insight into how pancreas development is affected by IUGR, while the sheep provides a model system more reminiscent of human pancreas development (Table 3). Regardless of species, critical windows of islet development include differentiation, proliferation, development of vasculature, and functional maturation of metabolism (Fig. 1); all of these are potentially affected by fetal nutrient restriction.

\section{$\beta$-cell deficiencies in animal models of IUGR}

In addition to obvious ethical issues, studies in humans are difficult because of our long life span, during which time complex environmental and genetic factors may cloud associations between fetal growth and adulthood diseases. Therefore, animal models of IUGR play a critical role in building our understanding of developmental programing of $\beta$-cells. Although no model perfectly replicates human circumstances, all of the rodent and sheep models discussed here show a clear association between fetal growth restriction and $\beta$-cell dysfunction (Table 2). However, the mechanisms for these adverse outcomes differ (Fig. 1), which may reflect the type, timing, and duration of fetal insults.

\section{Rodent models of IUGR}

Uterine artery ligation model Abrupt global nutrient and oxygen restriction is created by uterine artery ligation (UAL) in rats at E18-E19 (term is 22 days), causing IUGR (Table 2; Wigglesworth 1964, Ogata et al. 1986, Simmons et al. 1992). The period of fetal insult is relatively brief, with reductions in fetal $\mathrm{pH}$ and oxygen lasting for 1-2 days, and plasma glucose and insulin being reduced for $2-3$ days prior to normalizing by birth (Ogata et al. 1986, Peterside et al. 2003). Simmons et al. (2001) have shown that UAL rat pups exhibit 


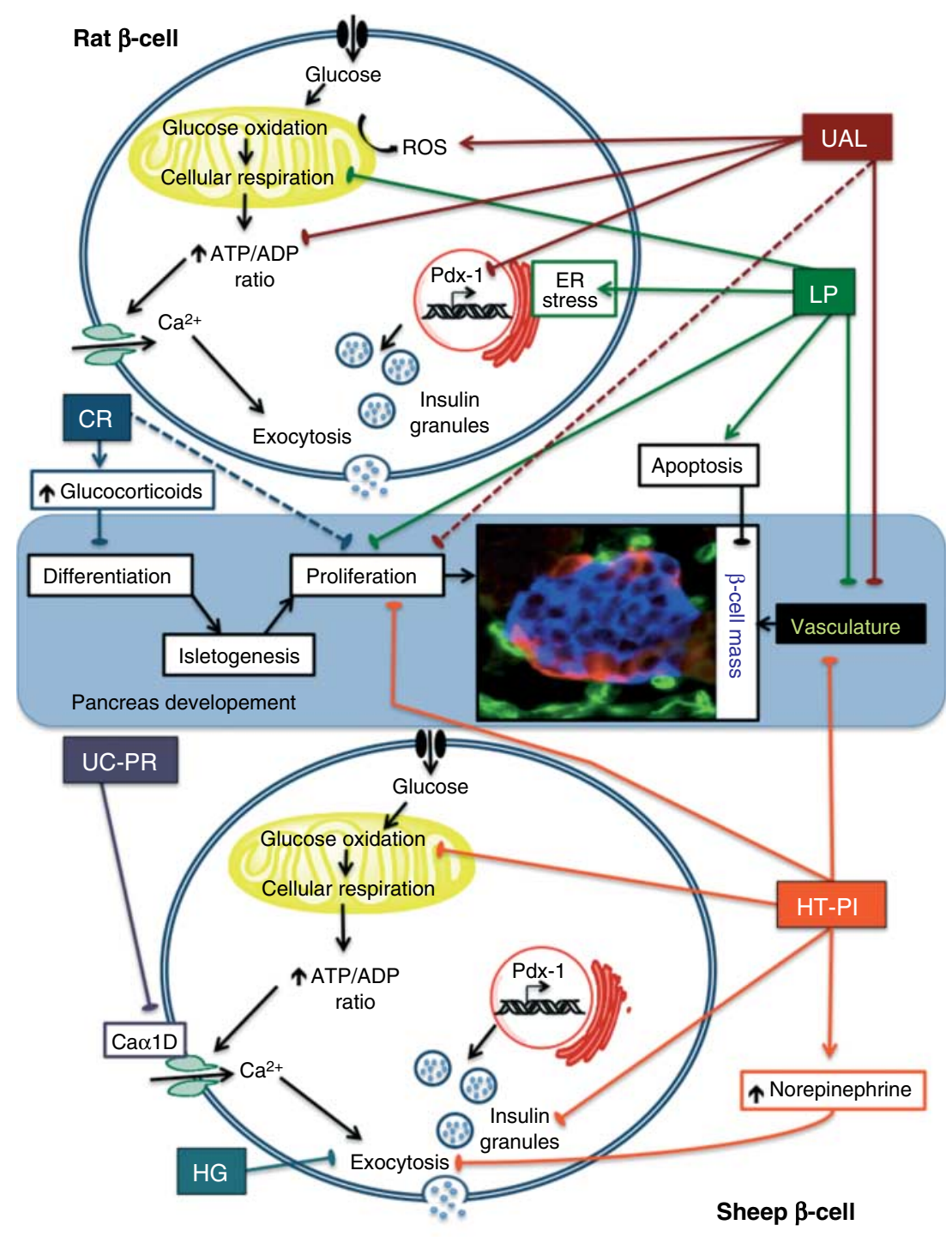

Figure 1 Mechanisms for $\beta$-cell dysfunction in models of IUGR. A schematic representation of pancreas development and processes controlling $\beta$-cell function is depicted. Identified $\beta$-cell impairments are shown for each of the rat (above) and sheep (below) models of IUGR. Rat IUGR models include uterine artery ligation (UAL), low-protein diet (LP) and caloric restriction (CR). Sheep IUGR models include uterine carunclectomy-placental restriction (UC-PR), chronic hypoglycemia (HG), and hyperthermia-induced placental insufficiency (HT-PI). A fetal sheep islet at $103 \mathrm{dGA}$ is shown in the micrograph; it is immunostained for insulin ( $\beta$-cell, blue), other endocrine cells (glucagon, somatostatin, and pancreatic polypeptide cells, red), and vasculature (Griffonia simplicifolia 1, green). Solid lines indicate processes sensitive to nutrient restriction in the fetus; dashed lines indicate postnatal effects. Lines ending with arrows represent enhancement, and lines ending with bars represent inhibition of the defined processes. ER, endoplasmic reticulum; ROS, reactive oxygen species; Ca $\alpha 1 \mathrm{D}$, voltage-gated calcium channel $\alpha 1 \mathrm{D}$.

catch-up growth and surpass controls, becoming obese by 26 weeks. No irregularities in pancreas $\beta$-cell morphology are observed before 7 weeks of age, but by 15 weeks, $\beta$-cell mass is $50 \%$ of controls and continues to decline thereafter (Simmons et al. 2001). B-Cell proliferation is lower at postnatal day $(\mathrm{P})$ 14, which is associated with reductions in islet vascular density or other underlying $\beta$-cell defects that take several weeks to manifest (Stoffers et al. 2003, Ham et al. 2009). Interestingly, when UAL is conducted on rats at E17, just 1 day earlier than in the studies by Simmons et al. (2001), 
$\beta$-cell mass is reduced at P1 (De Prins \& Van Assche 1982). Thus, earlier timing of UAL targets a different stage of pancreas development, causing reductions in $\beta$-cell mass and differentiation rather than impairments in maturation.

Fasting glucose and insulin concentrations are normal in UAL rats at P7, but they develop mild fasting hyperglycemia and hyperinsulinemia by 7 weeks and frank diabetes by 26 weeks of age. Insulin secretion stimulated with either glucose or leucine is impaired in newborns and progressively worsens with age, but responsiveness to arginine remains intact (Simmons et al. 2001, 2005). These findings indicate that the $\beta$-cell defect is in metabolic coupling rather than a deficiency in the releasable pool of insulin (Simmons et al. 2001).

Mitochondrial dysfunction and oxidative stress are potential underlying mechanisms for $\beta$-cell dysfunction in UAL rats (Simmons et al. 2005). ATP production in response to glucose is lower in UAL islets compared with controls, which is partially explained by deficiencies in the mitochondrial electron transport chain and in greater mitochondrial DNA point mutations (Simmons et al. 2005). Reactive oxygen species (ROS) production is also chronically elevated in UAL islets (Simmons et al. 2005), probably potentiated by hyperglycemia (Robertson \& Harmon 2006). These factors likely create a self-supporting cycle in which abrupt fetal hypoxemia impairs mitochondrial function, which lowers the activity of the electron transport chain and augments ROS production, leading to further damage (Li et al. 2004).

$P d x 1$ mRNA expression is lower in UAL fetuses (50\%) and adults $(80 \%)$, and it has been shown to be downregulated by modification that silences heterochromatin (Park et al. 2008). In addition to transactivation of $\beta$-cell-specific genes, $P d x 1$ also regulates mitochondrial function in mature $\beta$-cells (Gauthier et al. 2004). In UAL fetuses, histone deacetylase 1 and $\operatorname{Sin} 3 \mathrm{~A}$ are recruited to the proximal promoter region, deacetylating core histones $\mathrm{H} 3$ and $\mathrm{H} 4$ and repressing $P d x 1$. Demethylation of lysine 4 and methylation of lysine 9 on histone $\mathrm{H} 3$ also occur, reflecting alternative modifications to the core histones that result in the loss of USF-1 binding to PDX1 promoter. Finally, DNA methylation of the $P d x 1$ gene further suppresses its expression in adult UAL rats (Park et al. 2008). These data provide evidence linking several of the cellular impairments associated with mitochondrial dysfunction to epigenetic modifications.

Neonatal treatment (P0-P6) with exendin-4, a long-acting GLP-1 analog, prevents the loss of $\beta$-cell mass and normalizes $\beta$-cell proliferation in UAL pups (Stoffers et al. 2003). Exendin-4 treatment normalizes islet vascularity and VEGF protein expression (Ham et al. 2009), which may explain the improvements in proliferation. Fasting glycemia and glucose tolerance are also restored, and the development of diabetes is averted (Stoffers et al. 2003). Pdx 1 expression is maintained with exendin-4 treatment (Stoffers et al. 2003), further confirming $P d x 1$ as a major point for $\beta$-cell programing in the UAL model.
Calorie restriction model Maternal calorie restriction (CR; $50 \%$ of control energy intake in most studies) of rat dams during the last week of gestation causes a $12-20 \%$ reduction in birth weight in about half of fetuses, which are selected as IUGR (Table 2; Garofano et al. 1997, 1998b). One-day-old CR-IUGR pups have reduced pancreas weight, insulin content, islet density, and $\beta$-cell mass, but islet size is similar to controls (Garofano et al. 1997, 1998a, Dumortier et al. 2007). $\beta$-Cell proliferation and apoptosis and islet vascularity are not different at E21 or P1. However, CR islets (E15) have fewer $N g n 3$ and $P d x 1$ positive cells, indicating that $\beta$-cell differentiation is impaired (Garofano et al. 1997, 1998a, Dumortier et al. 2007). However, when $\mathrm{CR}$ is extended through lactation, additional declines in $\beta$-cell mass, number, and insulin content are observed in adulthood, indicating that $\beta$-cells are also susceptible to nutrient restriction after differentiation is complete (Garofano et al. 1998a,b, 1999).

Both aging and pregnancy are normal physiological stresses, and $\beta$-cells of CR rats appear to be poorly equipped to tolerate these events. During pregnancy, the endocrine pancreas of the mother normally expands by replication to overcome insulin resistance (Blondeau et al. 1999, Avril et al. 2002). However, 8-month-old CR rats, malnourished through weaning and fed an adequate diet thereafter, display an inability to expand their $\beta$-cell population and are hypoinsulinemic at midpregnancy (Blondeau et al. 1999, Avril et al. 2002). Interestingly, 4-month-old CR rats display normal adaptations to pregnancy, implicating an interaction between age and pregnancy in the plasticity of the adult CR pancreas (Blondeau et al. 1999). Nonpregnant rats also normally increase $\beta$-cell mass by $40 \%$ by replication between 3 and 12 months of age; however, CR rats do not show this increase, resulting in reduced insulin secretion (Garofano et al. 1999).

CR fetuses have elevated glucocorticoid concentrations, which has been proposed as a mechanism for the observed $\beta$-cell dysfunction (Blondeau et al. 2001). Studies on pancreas development in vitro and in glucocorticoid receptor knockout mice show that glucocorticoids impair normal $\beta$-cell differentiation and lower $P d x 1$ expression (Gesina et al. 2004, 2006). In normal rat fetuses, there is a negative correlation between plasma corticosterone and fetal weight, as well as pancreatic insulin content (Blondeau et al. 2001). When CR rat dams are subjected to adrenalectomy and then exogenously supplemented with normal levels of corticosterone, fetal $\beta$-cell fraction and mass are restored despite CR (Blondeau et al. 2001, Lesage et al. 2001). Fetal body weight and pancreas weight are still reduced (Blondeau et al. 2001, Lesage et al. 2001), indicating that elevated glucocorticoids have a $\beta$-cell-specific effect, while malnutrition still impacts other aspects of fetal development.

Low-protein diet model Feeding dams a low-protein (LP) isocalorie diet ( 8 vs 20\% dietary protein) throughout gestation causes IUGR and lowers fetal and postnatal pancreas 
weight, $\beta$-cell mass, and islet size (Table 2; Snoeck et al. 1990, Dahri et al. 1991, Petrik et al. 1999b, Boujendar et al. 2002). In contrast to $\mathrm{CR}$ offspring, $\beta$-cell differentiation progresses normally in LP fetuses (Dumortier et al. 2007). However, at E21.5 islet cell proliferation is lower due to a longer $G_{1}$ phase, and apoptosis is increased (Petrik et al. 1999b, Boujendar et al. 2002). These changes are associated with lower islet insulin-like growth factor 2 (IGF2) expression, which if overexpressed can cause $\beta$-cell hyperplasia (Petrik et al. 1998, $1999 a, b)$. Moreover, these effects may be influenced by lower islet vascularity and by depressed expression of VEGF and VEGF receptor 2, reminiscent of the UAL model (Snoeck et al. 1990, Boujendar et al. 2003, Dumortier et al. 2007).

One study attempted to separate temporal effects by feeding the LP diet during either gestation or lactation or throughout both periods (Berney et al. 1997). In all circumstances, protein restriction reduced $\beta$-cell area and caused islets to be irregularly shaped in weanlings. However, postnatal protein restriction caused greater reductions in $\beta$-cell and islet numbers, fitting temporally with the postnatal $\beta$-cell expansion and isletogenesis. In addition, feeding an LP diet during just the last week of gestation had a greater impact on fetal $\beta$-cell mass than LP feeding throughout gestation, indicating that the dam is able to compensate for protein restriction to some extent when it is initiated earlier (Dumortier et al. 2007). These data indicate that timing of protein restriction relative to pancreas development is critical for determining $\beta$-cell outcomes in offspring.

Impaired islet insulin responsiveness to amino acids and theophylline is observed in vitro in LP fetal islets; however, neither control nor LP fetal islets $(E 21 \cdot 5)$ responded to glucose (Dahri et al. 1991, Cherif et al. 1996, 1998). As adults, LP rats demonstrate impaired glucose tolerance but do not develop diabetes (Dahri et al. 1991). In postnatal LP islets, $\beta$-cell metabolism is decreased, likely lowering $\beta$-cell response to insulin secretagogues (Sener et al. 1996, Goosse et al. 2009).

Additional studies have shown that LP islets have increased nitric oxide production in unstimulated islets (Goosse et al. 2009 ) and increased sensitivity to nitric oxide- and IL-1 $\beta$ induced apoptosis (Merezak et al. 2001). The transcription factor growth arrest and DNA damage inducible-protein 153 (GADD153 that is listed as DDIT3 in the HUGO Database) mRNA and protein expressions are increased in LP islets, implicating endoplasmic reticulum stress pathways in $\beta$-cell dysfunction (Goosse et al. 2009). Furthermore, LP islets develop an imbalance in antioxidant enzyme expression, likely increasing susceptibility to oxidative stress (Theys et al. 2009).

Plasma taurine is lower in LP dams and their fetuses. Taurine has many physiological functions, including serving as an antioxidant (Huxtable 1992). It is considered an essential amino acid for fetal and neonatal development, because in vivo synthesis is inadequate at these ages (Huxtable 1992, Sturman 1993, Aerts \& Van Assche 2002). Taurine supplementation of LP dams during pregnancy normalizes islet responsiveness, IGF2, and vascularity, as well as $\beta$-cell proliferation, apoptosis, and mass (Cherif et al. 1998, Boujendar et al. 2002, 2003).
However, fetal and pup body weights are not corrected (Boujendar et al. 2002). Thus, LP feeding appears to have $\beta$-cell-specific effects, which may be caused by a taurine deficiency rather than by global protein malnutrition.

\section{Sheep models of IUGR}

Hyperthermia-induced placental insufficiency Pregnant ewes chronically exposed to elevated ambient temperatures from early to late gestation have fetuses that are growth restricted close to term $(135$ dGA, term $\sim 147$; Bell et al. 1987, Regnault et al. 1999, 2002). Smaller placentae with a decreased capacity to transport oxygen and nutrients from the mother to the fetus cause the fetus to become hypoxemic and hypoglycemic (Table 2; Thureen et al. 1992, Limesand et al. 2004, 2007, de Vrijer et al. 2004), causing growth restriction in the hyperthermia-induced placental insufficiency (HT-PI) model. Biometric parameters and fetal weight begin to diverge from normal after $70 \mathrm{dGA}$, just after the apex of placental growth, and worsen as gestation continues, demonstrating that the placenta is unable to adequately supply fetal demands for growth (Galan et al. 1999, Regnault et al. 2002, 2003).

Although asymmetric fetal growth is apparent, fetal adaptations appear to target the $\beta$-cells to a great extent (Limesand et al. 2005). At $133 \mathrm{dGA}(0 \cdot 9$ of gestation), HT-PI pancreas weight parallels the fetal growth reduction $(-59 \%)$, but $\beta$-cell mass is lower $(-76 \%)$ due to fewer $\beta$-cells (Limesand et al. 2005). This is the result of an extended cell cycle, because $\beta$-cell mitosis is $72 \%$ lower in HT-PI islets (Limesand et al. 2005). $\beta$-Cell differentiation may also be impaired, because $\beta$-cells in the extra-islet compartment, which might represent newly formed $\beta$-cells, are decreased in the HT-PI pancreas; however, changes in isletogenesis could also explain this difference (Limesand et al. 2005). Together, these results indicate that placental insufficiency decreases the number of $\beta$-cells (Limesand et al. 2005).

HT-PI fetuses also have impaired insulin secretion, measured by GSIS and glucose-potentiated arginine-induced insulin secretion (GPAIS; Table 1; Limesand et al. 2006, 2007). Glucose-stimulated insulin release by fetal islets, expressed as a fraction of total insulin content, is greater in HT-PI islets than in controls, but the amount of insulin released per HT-PI islet is significantly less due to lower insulin contents (82\%). HT-PI islets also demonstrate a deficiency in glucose metabolism; they are unresponsive to glucose-enhanced oxidative metabolism, but glucose utilization rates are intact (Limesand et al. 2006). Therefore, IUGR islets have impaired insulin secretion due to reduced insulin biosynthesis and storage, which might be partially in response to impaired oxidative metabolism. However, IUGR islets appear to compensate for these deficits to some extent by augmenting their capacity to release insulin.

Placental insufficiency causes fetal HG and hypoxemia, both of which can independently lower insulin. Chronic HG without hypoxemia, which is discussed as a separate model 
below, results in moderate impairment of insulin secretion. Conversely, when glucose is intravenously replaced in HT-PI fetuses for 2 weeks, it is not well tolerated and fails to correct insulin secretion (Rozance et al. 2009b), confirming that hypoxemia in addition to HG contributes to the $\beta$-cell dysfunction. The suppressive effects of hypoxemia on $\beta$-cell function may be directly related to the elevation in catecholamines. Acute bouts of asphyxia cause plasma norepinephrine concentrations to rise in fetal sheep, and via the $\alpha_{2}$-adrenergic receptors, norepinephrine suppresses insulin release (Cheung 1990, Milley 1997, Jackson et al. 2000). In human fetuses, norepinephrine concentrations are also increased during hypoxia and are higher in IUGR fetuses (Paulick et al. 1985, Greenough et al. 1990). We have shown that GSIS can be restored in HT-PI fetuses with adrenergic receptor blockade (Leos et al. 2010). This recovery in insulin secretion happens even though fewer $\beta$-cells are present, suggesting that the $\beta$-cells are hyperresponsive, which is also observed in the isolated islets and persists in the HT-PI lambs at P8 (S W Limesand, R A Leos and MJ Anderson, unpublished observations). These findings could begin to explain the mismatch in insulin secretion and glucose disposal rate observed in IUGR infants (Bazaes et al. 2003).

\section{Uterine carunclectomy model of placental} restriction Another well-established sheep model of IUGR is produced by removing most of the endometrial caruncles from the uterus prior to pregnancy, resulting in placental restriction (UC-PR; Robinson et al. 1979). In contrast to humans and rodents, sheep and other ruminants have a cotyledonary placenta that consists of many placentomes. These are discrete units of maternal-fetal interface for gas and nutrient exchange formed by the maternal caruncle and the fetal cotyledon (chorion). Thus, removing the endometrial caruncles lowers the number of sites for placentation in the subsequent pregnancy and reduces placenta size and function (Robinson et al. 1979). UC-PR fetuses are smaller compared with controls, hypoxemic ( -23 to $35 \%$ ), and hypoglycemic ( -15 to $41 \%$ ) in late gestation (Table 2; Robinson et al. 1979, Owens et al. 1989, 2007). Catecholamine (Simonetta et al. 1997) and cortisol (Phillips et al. 1996) concentrations are also increased during late gestation.

In UC-PR fetuses, Owens et al. (2007) have shown that fetal hypoxemia and HG are associated with deficiencies in acute $\beta$-cell responsiveness, demonstrated by decreased insulin secretion during intravenous glucose tolerance tests (IVGTT; Table 1) and intravenous arginine stimulation tests (IVAST; Table 1). Importantly, the loss of acute insulin secretion is a hallmark of T2DM (Ward et al. 1984, Kahn et al. 2001). IVGTT and IVAST measure only first-phase insulin secretion, while the GPAIS test used in the HT-PI model measures maximal insulin release (Robertson 2007). Therefore, reductions in insulin secretion may be even more pronounced in UC-PR fetuses than indicated by the IVGTT/IVAST. No differences are found in $\beta$-cell area or mass in UC-PR fetuses compared with controls
(Gatford et al. 2008). However, fetal weight does positively correlate with $\beta$-cell mass, indicating a similar, though attenuated, response compared with HT-PI fetuses.

UC-PR offspring also suffer postnatal consequences. Young lambs and young adult sheep exhibit impaired glucose tolerance due to $\beta$-cell insufficiencies that are associated with reduced body weight or thinness at birth (De Blasio et al. 2007). In young IUGR lambs, IVGTT reveal depressed insulin secretion during the first $15 \mathrm{~min}$ and a marginally lower insulin disposition that appears to be spared by improved insulin sensitivity (De Blasio et al. 2007). In adulthood, however, birth weight is negatively correlated with $\beta$-cell mass in males but positively correlated with glucose disposition (Table 1), suggesting that a greater number of $\beta$-cells are required to maintain glucose homeostasis in UC-PR adults (Gatford et al. 2008). IGF1 and 2, determinants for $\beta$-cell growth, are elevated in the pancreas of month-old UC-PR lambs, and these growth factors are postulated to be associated with neonatal catch-up growth (Gatford et al. 2008). The expression of the voltagegated calcium channel $\alpha 1 \mathrm{D}$ is decreased and is positively correlated with $\beta$-cell function, identifying a candidate gene for $\beta$-cell dysfunction in the stimulus-secretion coupling (Gatford et al. 2008).

Chronic hypoglycemia Experimental HG can be established in fetal sheep to measure $\beta$-cell outcomes in a system relatively independent of other common complications usually associated with placental insufficiency, such as hypoxemia. A maternal insulin infusion lowers both maternal and fetal arterial plasma glucose concentrations by about $50 \%$ and is maintained for 10-14 days (DiGiacomo \& Hay 1990). Maternal insulin does not cross the placenta, and therefore, fetal insulin concentrations decrease markedly in response to HG. Uterine and umbilical blood flows are maintained, as are fetal oxygen, oxygen uptake, and amino acid uptake, but fetuses are smaller than control fetuses (Table 2; DiGiacomo \& Hay 1990, Limesand et al. 2009). Other changes relevant to $\beta$-cell function include alterations in fetal plasma amino acid profiles, with notable increases in taurine and lysine. Cortisol is also elevated, but catecholamines remain normal (Limesand \& Hay 2003, Rozance et al. 2008).

Fetal GSIS and GPAIS are lower in HG fetuses (Carver et al. 1996, Limesand \& Hay 2003). Nonlinear modeling of insulin secretion during a square-wave hyperglycemic clamp reveals a delay in insulin release (Limesand \& Hay 2003). Morphological analysis of the endocrine pancreas shows that $\beta$-cell mass and insulin content are maintained, indicating that the blunted insulin secretion is due to a functional $\beta$-cell defect. In vitro, despite an ability to utilize and oxidize glucose normally, glucose- and amino acid-stimulated insulin secretions are completely absent, indicating an intrinsic $\beta$-cell defect in insulin granule exocytosis (Rozance et al. 2006, 2007). Therefore, chronic HG blunts insulin secretion as a result of deficiencies in later steps of stimulus-secretion coupling after glucose metabolism, membrane depolarization, 
and calcium entry. The $\beta$-cell impairment in chronically HG fetuses is clearly distinct from the HT-PI model, showing that $\mathrm{HG}$ alone can create islet dysfunction during late gestation.

Five days of euglycemic correction after 14 days of fetal HG normalizes insulin concentrations during the euglycemic and hyperglycemic clamp periods. However, the time required to reach maximal insulin concentrations remains delayed, and GPAIS does not recover (Limesand \& Hay 2003). These data confirm that chronic HG can cause persistent impairments in $\beta$-cell function, similar to the findings in the UC-PR model.

\section{Consequences to $\beta$-cells in IUGR models}

Animal models of IUGR provide useful insights into potential mechanisms for $\beta$-cell programing in response to nutrient or oxygen deprivation (Fig. 1). Advantages of rats as a model species include a short gestation period and lifespan, making them useful for studying adulthood and multigenerational effects of IUGR. Moreover, pancreas development in rodents progresses in relatively discrete stages (Table 3), which allows us to link $\beta$-cell defects to distinct developmental transitions. For example, CR throughout gestation targets $\beta$-cell differentiation, whereas UAL in late gestation targets $\beta$-cell maturation and proliferation (Table 2). Other factors contribute to these outcomes; a primary factor in CR rats appears to be elevated glucocorticoids, whereas epigenetic changes that lower $\mathrm{Pdx}-1$ transcription are central to the UAL $\beta$-cell dysfunction. Offspring from all three rat models exhibit reduced $\beta$-cell proliferation, which might reflect vascular deficiencies and/or lower growth factor concentrations. Defects in $\beta$-cell metabolism have also been identified in UAL and LP offspring, indicating that inefficient insulin secretion responsiveness can continue to take a toll postnatally. Overall, the rodent models show that impaired $\beta$-cell function can persist long after the intrauterine complications, and these deficiencies impact a variety of aspects coordinating $\beta$-cell mass and function.

The fetal sheep has proven to be a valuable model for studying the pathogenesis of IUGR and will continue to extend our knowledge of how IUGR alters the multifocal pancreas development pattern found in both sheep and humans (Table 3). Of the three ovine models, HT-PI results in the greatest reduction in $\beta$-cell mass. The UC-PR model causes a more moderate IUGR (Table 2 ), but $\beta$-cell mass is still correlated with fetal weight. This correlation between the degree of IUGR and the reduction in $\beta$-cell mass is reminiscent of the pattern seen in the human studies: severe IUGR cases have lower $\beta$-cell mass (Van Assche et al. 1977), but there is no evidence for this in moderate IUGR (Beringue et al. 2002). Timing of fetal nutrient restriction is also a factor. HT-PI begins after mid-gestation and causes lower $\beta$-cell mass than the HG and UC-PR models, for which nutrient restriction occurs only during the final $20 \%$ of gestation. The degree of fetal HG is similar in the HT-PI and HG models, but islet responses are different, further highlighting the importance of discrepancies in the duration and timing of nutrient restriction. However, similar to the rat models, IUGR in sheep impairs a variety of aspects important for $\beta$-cell function, including proliferation, insulin storage, glucose metabolism, or exocytosis (Fig. 1).

\section{Future directions in IUGR research}

While there is strong evidence for an association between human IUGR and $\beta$-cell programing, there is a paucity of data on insulin sensitivity, glucose metabolism, and $\beta$-cell function in truly IUGR infants. Therefore, another prospective study with assessments throughout lifespan is needed to verify the results of Mericq and colleagues (Soto et al. 2003). In addition to metabolic and morphometric evaluations, it will be critical to include measurements of initiators of $\beta$-cell dysfunction described in animal models (e.g. catecholamine and glucocorticoid concentrations). Furthermore, we have little knowledge of $\beta$-cell mass in IUGR patients at birth or throughout lifespan. These data could be obtained from autopsy studies, but in vivo real-time measurements of $\beta$-cell mass would obviously be more advantageous. The emerging technologies of in vivo imaging and quantification of $\beta$-cell mass (Sweet et al. 2004, Souza et al. 2006) will be useful for this purpose and could be performed concurrently with a complete in vivo assessment.

Future research is also needed to develop interventions that can improve outcomes in IUGR patients by rescuing $\beta$-cell function and preventing obesity, insulin resistance, and T2DM. Nutritional interventions in mothers at risk for or with IUGR fetuses have shown mixed results, in some cases worsening perinatal growth and increasing mortality (Rush et al. 1980, Harding \& Charlton 1989, Kramer \& Kakuma 2003). Thus, interventions should be pursued only after appropriate animal testing. The fetal sheep is an excellent model for this purpose, because fetal conditions can be precisely regulated for discrete periods of gestation to mimic features of placental insufficiency-induced IUGR and to test the impact of potential treatments on fetal $\beta$-cell function and metabolism. Using the catheterized fetal sheep preparation, the impact of chronic supplementation of fetal glucose (Rozance et al. 2009b), amino acids (Rozance et al. 2009a), IGF1 (Eremia et al. 2007), and insulin (Carson et al. 1980) on fetal metabolism has been measured in control and IUGR fetuses. These studies should be expanded to optimize conditions for IUGR fetuses, with the ultimate goal of identifying treatments that can be administered through the mother to rescue fetal $\beta$-cell function and mass.

\section{Conclusions}

IUGR is associated with impaired glucose tolerance and T2DM later in life, and there is evidence that insulin secretion defects contribute to these outcomes. Animal models of 
IUGR are critical for defining potential mechanisms of $\beta$-cell dysfunction. They have thus far demonstrated that $\beta$-cell dysfunction can be reached by multiple mechanisms (Fig. 1), likely depending on the type, timing, and duration of fetal malnutrition and how these factors coincide with stages of pancreas development. There is currently little data from which to determine which, if any, of the identified mechanisms may cause the insulin secretion defect in humans, highlighting the need for more human studies. Animal studies will continue to be important to expand and refine our knowledge of mechanisms, as well as to test potential therapies that may ultimately be used to improve outcomes in human IUGR patients.

\section{Declaration of interest}

The authors declare that there is no conflict of interest that could be perceived as prejudicing the impartiality of the research reported.

\section{Funding}

This work was supported by Award Number R01DK084842 (Principle Investigator SWL) from the National Institute of Diabetes and Digestive and Kidney Diseases. ASG was supported by an NIH Institutional Training Grant (Interdisciplinary Training in Cardiovascular Research, HL07249) and F32DK088514 from the National Institute of Diabetes and Digestive and Kidney Diseases. PJR was supported by an American Diabetes Association Junior Faculty Award (7-08-JF-51) and a National Institute of Child Health and Human Development Career Development Award (1K08HD060688-01). The content is solely the responsibility of the authors and does not necessarily represent the official views of the National Institute of Diabetes and Digestive and Kidney Diseases, National Institute of Child Health and Human Development, or the National Institutes of Health.

\section{References}

Adam PA, Teramo K, Raiha N, Gitlin D \& Schwartz R 1969 Human fetal insulin metabolism early in gestation. Response to acute elevation of the fetal glucose concentration and placental tranfer of human insulin-I-131. Diabetes 18 409-416.

Aerts L \& Van Assche FA 2002 Taurine and taurine-deficiency in the perinatal period. Journal of Perinatal Medicine 30 281-286.

Aldoretta PW, Carver TD \& Hay WW Jr 1998 Maturation of glucosestimulated insulin secretion in fetal sheep. Biology of the Neonate 73 375-386.

Avril I, Blondeau B, Duchene B, Czernichow P \& Breant B 2002 Decreased $\beta$-cell proliferation impairs the adaptation to pregnancy in rats malnourished during perinatal life. Journal of Endocrinology 174 215-223.

Barker DJ, Hales CN, Fall CH, Osmond C, Phipps K \& Clark PM 1993 Type 2 (non-insulin-dependent) diabetes mellitus, hypertension and hyperlipidaemia (syndrome $\mathrm{X}$ ): relation to reduced fetal growth. Diabetologia 36 62-67.

Bazaes RA, Salazar TE, Pittaluga E, Pena V, Alegria A, Iniguez G, Ong KK, Dunger DB \& Mericq MV 2003 Glucose and lipid metabolism in small for gestational age infants at 48 hours of age. Pediatrics 111 804-809.

Bazaes RA, Alegria A, Pittaluga E, Avila A, Iniguez G \& Mericq V 2004 Determinants of insulin sensitivity and secretion in very-low-birth-weight children. Journal of Clinical Endocrinology and Metabolism 89 1267-1272.

Bell AW, Wilkening RB \& Meschia G 1987 Some aspects of placental function in chronically heat-stressed ewes. Journal of Developmental Physiology 9 17-29.
Beringue F, Blondeau B, Castellotti MC, Breant B, Czernichow P \& Polak M 2002 Endocrine pancreas development in growth-retarded human fetuses. Diabetes 51 385-391.

Berney DM, Desai M, Palmer DJ, Greenwald S, Brown A, Hales CN \& Berry CL 1997 The effects of maternal protein deprivation on the fetal rat pancreas: major structural changes and their recuperation. Journal of Pathology 183 109-115.

Bhushan A, Itoh N, Kato S, Thiery JP, Czernichow P, Bellusci S \& Scharfmann R 2001 Fgf10 is essential for maintaining the proliferative capacity of epithelial progenitor cells during early pancreatic organogenesis. Development 128 5109-5117.

Blondeau B, Garofano A, Czernichow P \& Breant B 1999 Age-dependent inability of the endocrine pancreas to adapt to pregnancy: a long-term consequence of perinatal malnutrition in the rat. Endocrinology 140 4208-4213.

Blondeau B, Lesage J, Czernichow P, Dupouy JP \& Breant B 2001 Glucocorticoids impair fetal $\beta$-cell development in rats. American Journal of Physiology. Endocrinology and Metabolism 281 E592-E599.

Bocian-Sobkowska J, Zabel M, Wozniak W \& Surdyk-Zasada J 1999 Polyhormonal aspect of the endocrine cells of the human fetal pancreas. Histochemistry and Cell Biology 112 147-153.

del Bosque-Plata L, Lin J, Horikawa Y, Schwarz PE, Cox NJ, Iwasaki N, Ogata M, Iwamoto Y, German MS \& Bell GI 2001 Mutations in the coding region of the neurogenin 3 gene (NEUROG3) are not a common cause of maturity-onset diabetes of the young in Japanese subjects. Diabetes 50 694-696.

Boujendar S, Reusens B, Merezak S, Ahn MT, Arany E, Hill D \& Remacle C 2002 Taurine supplementation to a low protein diet during foetal and early postnatal life restores a normal proliferation and apoptosis of rat pancreatic islets. Diabetologia 45 856-866.

Boujendar S, Arany E, Hill D, Remacle C \& Reusens B 2003 Taurine supplementation of a low protein diet fed to rat dams normalizes the vascularization of the fetal endocrine pancreas. Journal of Nutrition 133 2820-2825.

Bouwens L, Lu WG \& De Krijger R 1997 Proliferation and differentiation in the human fetal endocrine pancreas. Diabetologia 40 398-404.

Carson BS, Philipps AF, Simmons MA, Battaglia FC \& Meschia G 1980 Effects of a sustained insulin infusion upon glucose uptake and oxygenation of the ovine fetus. Pediatric Research 14 147-152.

Carver TD, Anderson SM, Aldoretta PW \& Hay WW Jr 1996 Effect of low-level basal plus marked "pulsatile" hyperglycemia on insulin secretion in fetal sheep. American Journal of Physiology 271 E865-E871.

Cherif H, Reusens B, Dahri S, Remacle C \& Hoet JJ 1996 Stimulatory effects of taurine on insulin secretion by fetal rat islets cultured in vitro. Journal of Endocrinology 151 501-506.

Cherif H, Reusens B, Ahn MT, Hoet JJ \& Remacle C 1998 Effects of taurine on the insulin secretion of rat fetal islets from dams fed a low-protein diet. Journal of Endocrinology 159 341-348.

Cheung CY 1990 Fetal adrenal medulla catecholamine response to hypoxia-direct and neural components. American Journal of Physiology 258 R1340-R1346.

Cole L, Anderson MJ, Leos RA, Jensen J \& Limesand SW 2007 Progression of endocrine cell formation in the sheep pancreas. Diabetes $\mathbf{5 6}$ (Supplement 1) 1683.

Cole L, Anderson M, Antin PB \& Limesand SW 2009 One process for pancreatic $\beta$-cell coalescence into islets involves an epithelial-mesenchymal transition. Journal of Endocrinology 203 19-31.

Colle E, Schiff D, Andrew G, Bauer CB \& Fitzhardinge P 1976 Insulin responses during catch-up growth of infants who were small for gestational age. Pediatrics $\mathbf{5 7} 363-371$.

Collins JE \& Leonard JV 1984 Hyperinsulinism in asphyxiated and small-for-dates infants with hypoglycaemia. Lancet 2 311-313.

Collins JE, Leonard JV, Teale D, Marks V, Williams DM, Kennedy CR \& Hall MA 1990 Hyperinsulinaemic hypoglycaemia in small for dates babies. Archives of Disease in Childhood 65 1118-1120.

Creasy RK, Resnik R \& Iams J 2004 Maternal-Fetal Medicine: Principles and Practice. Philadelphia, PA: Saunders. 
Crowther NJ, Trusler J, Cameron N, Toman M \& Gray IP 2000 Relation between weight gain and $\beta$-cell secretory activity and non-esterified fatty acid production in 7-year-old African children: results from the Birth to Ten study. Diabetologia 43 978-985.

Dahri S, Snoeck A, Reusens-Billen B, Remacle C \& Hoet JJ 1991 Islet function in offspring of mothers on low-protein diet during gestation. Diabetes 40 (Suppl 2) 115-120.

De Blasio MJ, Gatford KL, McMillen IC, Robinson JS \& Owens JA 2007 Placental restriction of fetal growth increases insulin action, growth, and adiposity in the young lamb. Endocrinology 148 1350-1358.

De Prins FA \& Van Assche FA 1982 Intrauterine growth retardation and development of endocrine pancreas in the experimental rat. Biology of the Neonate 41 16-21.

DiGiacomo JE \& Hay WW Jr 1990 Fetal glucose metabolism and oxygen consumption during sustained hypoglycemia. Metabolism 39 193-202.

Dumortier O, Blondeau B, Duvillie B, Reusens B, Breant B \& Remacle C 2007 Different mechanisms operating during different critical time-windows reduce rat fetal $\beta$ cell mass due to a maternal low-protein or low-energy diet. Diabetologia 50 2495-2503.

Economides DL, Proudler A \& Nicolaides KH 1989 Plasma insulin in appropriate- and small-for-gestational-age fetuses. American Journal of Obstetrics and Gynecology 160 1091-1094.

Eremia SC, de Boo HA, Bloomfield FH, Oliver MH \& Harding JE 2007 Fetal and amniotic insulin-like growth factor-I supplements improve growth rate in intrauterine growth restriction fetal sheep. Endocrinology $1482963-2972$.

Ferrazzi E, Bozzo M, Rigano S, Bellotti M, Morabito A, Pardi G, Battaglia FC \& Galan HL 2002 Temporal sequence of abnormal Doppler changes in the peripheral and central circulatory systems of the severely growth-restricted fetus. Ultrasound in Obstetrics and Gynecology 19 140-146.

Flanagan DE, Moore VM, Godsland IF, Cockington RA, Robinson JS \& Phillips DI 2000 Fetal growth and the physiological control of glucose tolerance in adults: a minimal model analysis. American Journal of Physiology. Endocrinology and Metabolism 278 E700-E706.

Galan HL, Hussey MJ, Barbera A, Ferrazzi E, Chung M, Hobbins JC \& Battaglia FC 1999 Relationship of fetal growth to duration of heat stress in an ovine model of placental insufficiency. American Journal of Obstetrics and Gynecology 180 1278-1282.

Garofano A, Czernichow P \& Breant B 1997 In utero undernutrition impairs rat $\beta$-cell development. Diabetologia 40 1231-1234.

Garofano A, Czernichow P \& Breant B 1998a $\beta$-Cell mass and proliferation following late fetal and early postnatal malnutrition in the rat. Diabetologia 41 1114-1120.

Garofano A, Czernichow P \& Breant B $1998 b$ Postnatal somatic growth and insulin contents in moderate or severe intrauterine growth retardation in the rat. Biology of the Neonate 73 89-98.

Garofano A, Czernichow P \& Breant B 1999 Effect of ageing on $\beta$-cell mass and function in rats malnourished during the perinatal period. Diabetologia 42 711-718.

Gatford KL, Mohammad SN, Harland ML, De Blasio MJ, Fowden AL, Robinson JS \& Owens JA 2008 Impaired $\beta$-cell function and inadequate compensatory increases in $\beta$-cell mass after intrauterine growth restriction in sheep. Endocrinology 149 5118-5127.

Gauthier BR, Brun T, Sarret EJ, Ishihara H, Schaad O, Descombes P \& Wollheim CB 2004 Oligonucleotide microarray analysis reveals PDX1 as an essential regulator of mitochondrial metabolism in rat islets. Journal of Biological Chemistry 279 31121-31130.

Gerich JE 1998 The genetic basis of type 2 diabetes mellitus: impaired insulin secretion versus impaired insulin sensitivity. Endocrine Reviews 19 491-503.

Gesina E, Tronche F, Herrera P, Duchene B, Tales W, Czernichow P \& Breant B 2004 Dissecting the role of glucocorticoids on pancreas development. Diabetes 53 2322-2329.

Gesina E, Blondeau B, Milet A, Le NI, Duchene B, Czernichow P, Scharfmann R, Tronche F \& Breant B 2006 Glucocorticoid signalling affects pancreatic development through both direct and indirect effects. Diabetologia 49 2939-2947.
Goosse K, Bouckenooghe T, Balteau M, Reusens B \& Remacle C 2009 Implication of nitric oxide in the increased islet-cells vulnerability of adult progeny from protein-restricted mothers and its prevention by taurine. Journal of Endocrinology 200 177-187.

Gradwohl G, Dierich A, LeMeur M \& Guillemot F 2000 Neurogenin3 is required for the development of the four endocrine cell lineages of the pancreas. PNAS 97 1607-1611.

Greenough A, Nicolaides KH \& Lagercrantz H 1990 Human fetal sympathoadrenal responsiveness. Early Human Development 23 9-13.

Ham JN, Crutchlow MF, Desai BM, Simmons RA \& Stoffers DA 2009 Exendin-4 normalizes islet vascularity in intrauterine growth restricted rats: potential role of VEGF. Pediatric Research 66 42-46.

Harding JE \& Charlton V 1989 Treatment of the growth-retarded fetus by augmentation of substrate supply. Seminars in Perinatology 13 211-223.

Hoe FM, Thornton PS, Wanner LA, Steinkrauss L, Simmons RA \& Stanley CA 2006 Clinical features and insulin regulation in infants with a syndrome of prolonged neonatal hyperinsulinism. Journal of Pediatrics 148 207-212.

Hofman PL, Cutfield WS, Robinson EM, Bergman RN, Menon RK, Sperling MA \& Gluckman PD 1997 Insulin resistance in short children with intrauterine growth retardation. Journal of Clinical Endocrinology and Metabolism 82 402-406.

Huxtable RJ 1992 Physiological actions of taurine. Physiological Reviews $\mathbf{7 2}$ 101-163.

Iniguez G, Ong K, Bazaes R, Avila A, Salazar T, Dunger D \& Mericq V 2006 Longitudinal changes in insulin-like growth factor-I, insulin sensitivity, and secretion from birth to age three years in small-for-gestational-age children. Journal of Clinical Endocrinology and Metabolism 91 4645-4649.

Jackson BT, Piasecki GJ, Cohn HE \& Cohen WR 2000 Control of fetal insulin secretion. American Journal of Physiology. Regulatory, Integrative and Comparative Physiology 279 R2179-R2188.

Jensen J 2004 Gene regulatory factors in pancreatic development. Developmental Dynamics 229 176-200.

Jensen J, Heller RS, Funder-Nielsen T, Pedersen EE, Lindsell C, Weinmaster G, Madsen OD \& Serup P 2000 Independent development of pancreatic $\alpha$ - and $\beta$-cells from neurogenin3-expressing precursors: a role for the notch pathway in repression of premature differentiation. Diabetes 49 163-176.

Jensen CB, Storgaard H, Dela F, Holst JJ, Madsbad S \& Vaag AA 2002 Early differential defects of insulin secretion and action in 19-year-old caucasian men who had low birth weight. Diabetes 51 1271-1280.

Kahn SE, Prigeon RL, McCulloch DK, Boyko EJ, Bergman RN, Schwartz MW, Neifing JL, Ward WK, Beard JC \& Palmer JP 1993 Quantification of the relationship between insulin sensitivity and $\beta$-cell function in human subjects. Evidence for a hyperbolic function. Diabetes $\mathbf{4 2}$ 1663-1672.

Kahn SE, Montgomery B, Howell W, Ligueros-Saylan M, Hsu CH, Devineni D, McLeod JF, Horowitz A \& Foley JE 2001 Importance of early phase insulin secretion to intravenous glucose tolerance in subjects with type 2 diabetes mellitus. Journal of Clinical Endocrinology and Metabolism $\mathbf{8 6}$ 5824-5829.

Kassem SA, Ariel I, Thornton PS, Scheimberg I \& Glaser B 2000 B-Cell proliferation and apoptosis in the developing normal human pancreas and in hyperinsulinism of infancy. Diabetes 49 1325-1333.

Kervran A \& Randon J 1980 Development of insulin release by fetal rat pancreas in vitro: effects of glucose, amino acids, and theophylline. Diabetes 29 673-678.

Kervran A, Randon J \& Girard JR 1979 Dynamics of glucose-induced plasma insulin increase in the rat fetus at different stages of gestation. Effects of maternal hypothermia and fetal decapitation. Biology of the Neonate 35 242-248.

Kramer MS \& Kakuma R 2003 Energy and protein intake in pregnancy. Cochrane Database of Systematic Reviews Issue 4. Art no.: CD00032. DOI:10.1002/14651858.CD000032.

Lammert E, Cleaver O \& Melton D 2001 Induction of pancreatic differentiation by signals from blood vessels. Science 294 564-567.

Leos RA, Anderson MJ, Chen X, Pugmire JP, Anderson KA \& Limesand SW 2010 Chronic exposure to elevated norepinephrine suppresses insulin 
secretion in fetal sheep with placental insufficiency and intrauterine growth restriction. American Journal of Physiology. Endocrinology and Metabolism 298 E770-E778.

Lesage J, Blondeau B, Grino M, Breant B \& Dupouy JP 2001 Maternal undernutrition during late gestation induces fetal overexposure to glucocorticoids and intrauterine growth retardation, and disturbs the hypothalamo-pituitary adrenal axis in the newborn rat. Endocrinology 142 1692-1702.

Li C, Johnson MS \& Goran MI 2001 Effects of low birth weight on insulin resistance syndrome in caucasian and African-American children. Diabetes Care 24 2035-2042.

Li X, Chen H \& Epstein PN 2004 Metallothionein protects islets from hypoxia and extends islet graft survival by scavenging most kinds of reactive oxygen species. Journal of Biological Chemistry 279 765-771.

Limesand SW \& Hay WW Jr 2003 Adaptation of ovine fetal pancreatic insulin secretion to chronic hypoglycaemia and euglycaemic correction. Journal of Physiology 547 95-105.

Limesand SW, Regnault TR \& Hay WW Jr 2004 Characterization of glucose transporter 8 (GLUT8) in the ovine placenta of normal and growth restricted fetuses. Placenta 25 70-77.

Limesand SW, Jensen J, Hutton J \& Hay WW Jr 2005 Diminished $\beta$-cell replication contributes to reduced $\beta$-cell mass in fetal sheep with intrauterine growth restriction. American Journal of Physiology. Regulatory, Integrative and Comparative Physiology 288 R1297-R1305.

Limesand SW, Rozance PJ, Zerbe GO, Hutton JC \& Hay WW Jr 2006 Attenuated insulin release and storage in fetal sheep pancreatic islets with intrauterine growth restriction. Endocrinology 147 1488-1497.

Limesand SW, Rozance PJ, Smith D \& Hay WW Jr 2007 Increased insulin sensitivity and maintenance of glucose utilization rates in fetal sheep with placental insufficiency and intrauterine growth restriction. American Journal of Physiology. Endocrinology and Metabolism 293 E1716-E1725.

Limesand SW, Rozance PJ, Brown LD \& Hay WW Jr 2009 Effects of chronic hypoglycemia and euglycemic correction on lysine metabolism in fetal sheep. American Journal of Physiology. Endocrinology and Metabolism 296 E879-E887.

Merezak S, Hardikar AA, Yajnik CS, Remacle C \& Reusens B 2001 Intrauterine low protein diet increases fetal $\beta$-cell sensitivity to NO and IL-1 $\beta$ : the protective role of taurine. Journal of Endocrinology 171 299-308.

Mericq V, Ong KK, Bazaes R, Pena V, Avila A, Salazar T, Soto N, Iniguez G \& Dunger DB 2005 Longitudinal changes in insulin sensitivity and secretion from birth to age three years in small- and appropriate-for-gestational-age children. Diabetologia 48 2609-2614.

Milley JR 1997 Ovine fetal metabolism during norepinephrine infusion. American Journal of Physiology 273 E336-E347.

Molina RD, Carver TD \& Hay WW Jr 1993 Ontogeny of insulin effect in fetal sheep. Pediatric Research 34 654-660.

Newsome CA, Shiell AW, Fall CH, Phillips DI, Shier R \& Law CM 2003 Is birth weight related to later glucose and insulin metabolism? - a systematic review Diabetic Medicine 20 339-348.

Nicolini U, Hubinont C, Santolaya J, Fisk NM \& Rodeck CH 1990 Effects of fetal intravenous glucose challenge in normal and growth retarded fetuses. Hormone and Metabolic Research 22 426-430.

Nieto MA 2002 The snail superfamily of zinc-finger transcription factors. Nature Reviews. Molecular Cell Biology 3 155-166.

Nikolova G, Jabs N, Konstantinova I, Domogatskaya A, Tryggvason K, Sorokin L, Fassler R, Gu G, Gerber HP, Ferrara N et al. 2006 The vascular basement membrane: a niche for insulin gene expression and $\beta$ cell proliferation. Developmental Cell 10 397-405.

Norgaard GA, Jensen JN \& Jensen J 2003 FGF10 signaling maintains the pancreatic progenitor cell state revealing a novel role of Notch in organ development. Developmental Biology 264 323-338.

Offield MF, Jetton TL, Labosky PA, Ray M, Stein RW, Magnuson MA, Hogan BL \& Wright CV 1996 PDX-1 is required for pancreatic outgrowth and differentiation of the rostral duodenum. Development 122 983-995.

Ogata ES, Bussey ME \& Finley S 1986 Altered gas exchange, limited glucose and branched chain amino acids, and hypoinsulinism retard fetal growth in the rat. Metabolism 35 970-977.
Ong KK, Ahmed ML, Emmett PM, Preece MA \& Dunger DB 2000 Association between postnatal catch-up growth and obesity in childhood: prospective cohort study. BMJ 320 967-971.

Owens JA, Falconer J \& Robinson JS 1989 Glucose metabolism in pregnant sheep when placental growth is restricted. American Journal of Physiology 257 R350-R357.

Owens JA, Gatford KL, De Blasio MJ, Edwards LJ, McMillen IC \& Fowden AL 2007 Restriction of placental growth in sheep impairs insulin secretion but not sensitivity before birth. Journal of Physiology $\mathbf{5 8 4} 935-949$.

Park JH, Stoffers DA, Nicholls RD \& Simmons RA 2008 Development of type 2 diabetes following intrauterine growth retardation in rats is associated with progressive epigenetic silencing of Pdx1. Journal of Clinical Investigation 118 2316-2324.

Paulick R, Kastendieck E \& Wernze H 1985 Catecholamines in arterial and venous umbilical blood: placental extraction, correlation with fetal hypoxia, and transcutaneous partial oxygen tension. Journal of Perinatal Medicine 13 $31-42$.

Peterside IE, Selak MA \& Simmons RA 2003 Impaired oxidative phosphorylation in hepatic mitochondria in growth-retarded rats. American Journal of Physiology. Endocrinology and Metabolism 285 E1258-E1266.

Petrik J, Arany E, McDonald TJ \& Hill DJ 1998 Apoptosis in the pancreatic islet cells of the neonatal rat is associated with a reduced expression of insulin-like growth factor II that may act as a survival factor. Endocrinology 139 2994-3004.

Petrik J, Pell JM, Arany E, McDonald TJ, Dean WL, Reik W \& Hill DJ 1999a Overexpression of insulin-like growth factor-II in transgenic mice is associated with pancreatic islet cell hyperplasia. Endocrinology $\mathbf{1 4 0}$ 2353-2363.

Petrik J, Reusens B, Arany E, Remacle C, Coelho C, Hoet JJ \& Hill DJ 19996 A low protein diet alters the balance of islet cell replication and apoptosis in the fetal and neonatal rat and is associated with a reduced pancreatic expression of insulin-like growth factor-II. Endocrinology 140 4861-4873.

Philipps AF, Carson BS, Meschia G \& Battaglia FC 1978 Insulin secretion in fetal and newborn sheep. American Journal of Physiology 235 E467-E474.

Phillips ID, Simonetta G, Owens JA, Robinson JS, Clarke IJ \& McMillen IC 1996 Placental restriction alters the functional development of the pituitary-adrenal axis in the sheep fetus during late gestation. Pediatric Research 40 861-866.

Pictet R, Rutter WJ \& Geiger SR 1972a Development of the embryonic endocrine pancreas. In Handbook of Physiology. Endocrinology. Endocrine Pancreas. Section 7, Vol 1, pp 25-66. Ed. S R Geiger. Washington, DC: American Physiological Society.

Pictet RL, Clark WR, Williams RH \& Rutter WJ $1972 b$ An ultrastructural analysis of the developing embryonic pancreas. Developmental Biology 29 436-467.

Piper K, Brickwood S, Turnpenny LW, Cameron IT, Ball SG, Wilson DI \& Hanley NA $2004 \beta$-Cell differentiation during early human pancreas development. Journal of Endocrinology 181 11-23.

Platz E \& Newman R 2008 Diagnosis of IUGR: traditional biometry. Seminars in Perinatology 32 140-147.

Polak M, Bouchareb-Banaei L, Scharfmann R \& Czernichow P 2000 Early pattern of differentiation in the human pancreas. Diabetes 49 225-232.

Ravelli AC, van der Meulen JH, Michels RP, Osmond C, Barker DJ, Hales CN \& Bleker OP 1998 Glucose tolerance in adults after prenatal exposure to famine. Lancet 351 173-177.

Regnault TR, Orbus RJ, Battaglia FC, Wilkening RB \& Anthony RV 1999 Altered arterial concentrations of placental hormones during maximal placental growth in a model of placental insufficiency. Journal of Endocrinology 162 433-442.

Regnault TR, Galan HL, Parker TA \& Anthony RV 2002 Placental development in normal and compromised pregnancies. Placenta 23 S119-S129.

Regnault TR, de Vrijer B, Galan HL, Davidsen ML, Trembler KA, Battaglia FC, Wilkening RB \& Anthony RV 2003 The relationship between transplacental $\mathrm{O}_{2}$ diffusion and placental expression of PlGF, VEGF and their receptors in a placental insufficiency model of fetal growth restriction. Journal of Physiology 550 641-656.

Robertson RP 1992 Defective insulin secretion in NIDDM: integral part of a multiplier hypothesis. Journal of Cellular Biochemistry 48 227-233. 
Robertson RP 2007 Estimation of $\beta$-cell mass by metabolic tests: necessary, but how sufficient? Diabetes 56 2420-2424.

Robertson RP \& Harmon JS 2006 Diabetes, glucose toxicity, and oxidative stress: A case of double jeopardy for the pancreatic islet $\beta$ cell. Free Radical Biology \& Medicine 41 177-184.

Robinson JS, Kingston EJ, Jones CT \& Thorburn GD 1979 Studies on experimental growth retardation in sheep. The effect of removal of a endometrial caruncles on fetal size and metabolism. Journal of Developmental Physiology 1 379-398.

Rozance PJ, Limesand SW \& Hay WW Jr 2006 Decreased nutrientstimulated insulin secretion in chronically hypoglycemic late-gestation fetal sheep is due to an intrinsic islet defect. American Journal of Physiology. Endocrinology and Metabolism 291 E404-E411.

Rozance PJ, Limesand SW, Zerbe GO \& Hay WW Jr 2007 Chronic fetal hypoglycemia inhibits the later steps of stimulus-secretion coupling in pancreatic $\beta$-cells. American Journal of Physiology. Endocrinology and Metabolism 292 E1256-E1264.

Rozance PJ, Limesand SW, Barry JS, Brown LD, Thorn SR, LoTurco D, Regnault TR, Friedman JE \& Hay WW Jr 2008 Chronic late-gestation hypoglycemia upregulates hepatic PEPCK associated with increased PGC1 $\alpha$ mRNA and phosphorylated CREB in fetal sheep. American Journal of Physiology. Endocrinology and Metabolism 294 E365-E370.

Rozance PJ, Crispo MM, Barry JS, O'Meara MC, Frost MS, Hansen KC, Hay WW Jr \& Brown LD 2009a Prolonged maternal amino acid infusion in late-gestation pregnant sheep increases fetal amino acid oxidation. American Journal of Physiology. Endocrinology and Metabolism 297 E638-E646.

Rozance PJ, Limesand SW, Barry JS, Brown LD \& Hay WW Jr 2009 b Glucose replacement to euglycemia causes hypoxia, acidosis, and decreased insulin secretion in fetal sheep with intrauterine growth restriction. Pediatric Research 65 72-78.

Rush D, Stein Z \& Susser M 1980 A randomized controlled trial of prenatal nutritional supplementation in New York City. Pediatrics 65 683-697.

Rutter WJ 1980 The development of the endocrine and exocrine pancreas. In The Pancreas, pp 30-38. Eds PJ Fitzgerald \& AB Morrison. Baltimore: Williams \& Wilkins.

Sander M \& German MS 1997 The $\beta$ cell transcription factors and development of the pancreas. Journal of Molecular Medicine 75 327-340.

Sander M, Sussel L, Conners J, Scheel D, Kalamaras J, Dela CF, Schwitzgebel V, Hayes-Jordan A \& German M 2000 Homeobox gene $\mathrm{Nkx} 6.1$ lies downstream of $\mathrm{Nkx} 2.2$ in the major pathway of $\beta$-cell formation in the pancreas. Development 127 5533-5540.

Sarkar SA, Kobberup S, Wong R, Lopez AD, Quayum N, Still T, Kutchma A, Jensen JN, Gianani R, Beattie GM et al. 2008 Global gene expression profiling and histochemical analysis of the developing human fetal pancreas. Diabetologia 51 285-297.

Sener A, Reusens B, Remacle C, Hoet JJ \& Malaisse WJ 1996 Nutrient metabolism in pancreatic islets from protein malnourished rats. Biochemical and Molecular Medicine 59 62-67.

Setia S, Sridhar MG, Bhat V, Chaturvedula L, Vinayagamoorti R \& John M 2006 Insulin sensitivity and insulin secretion at birth in intrauterine growth retarded infants. Pathology 38 236-238.

Simmons RA, Gounis AS, Bangalore SA \& Ogata ES 1992 Intrauterine growth retardation: fetal glucose transport is diminished in lung but spared in brain. Pediatric Research 31 59-63.

Simmons RA, Templeton LJ \& Gertz SJ 2001 Intrauterine growth retardation leads to the development of type 2 diabetes in the rat. Diabetes 50 2279-2286.

Simmons RA, Suponitsky-Kroyter I \& Selak MA 2005 Progressive accumulation of mitochondrial DNA mutations and decline in mitochondrial function lead to $\beta$-cell failure. Journal of Biological Chemistry $28028785-28791$.

Simonetta G, Rourke AK, Owens JA, Robinson JS \& McMillen IC 1997 Impact of placental restriction on the development of the sympathoadrenal system. Pediatric Research 42 805-811.

Slack JM 1995 Developmental biology of the pancreas. Development 121 1569-1580.
Snoeck A, Remacle C, Reusens B \& Hoet JJ 1990 Effect of a low protein diet during pregnancy on the fetal rat endocrine pancreas. Biology of the Neonate 57 107-118.

Soto N, Bazaes RA, Pena V, Salazar T, Avila A, Iniguez G, Ong KK, Dunger DB \& Mericq MV 2003 Insulin sensitivity and secretion are related to catch-up growth in small-for-gestational-age infants at age 1 year: results from a prospective cohort. Journal of Clinical Endocrinology and Metabolism $\mathbf{8 8}$ 3645-3650.

Souza F, Freeby M, Hultman K, Simpson N, Herron A, Witkowsky P, Liu E, Maffei A \& Harris PE 2006 Current progress in non-invasive imaging of $\beta$ cell mass of the endocrine pancreas. Current Medicinal Chemistry 13 2761-2773.

Stoffers DA, Desai BM, DeLeon DD \& Simmons RA 2003 Neonatal exendin-4 prevents the development of diabetes in the intrauterine growth retarded rat. Diabetes $\mathbf{5 2}$ 734-740.

Sturman JA 1993 Taurine in development. Physiological Reviews 73 119-147.

Sugiyama T, Rodriguez RT, McLean GW \& Kim SK 2007 Conserved markers of fetal pancreatic epithelium permit prospective isolation of islet progenitor cells by FACS. PNAS 104 175-180.

Sweet IR, Cook DL, Lernmark A, Greenbaum CJ \& Krohn KA 2004 Non-invasive imaging of $\beta$ cell mass: a quantitative analysis. Diabetes Technology and Therapeutics 6 652-659.

Theys N, Clippe A, Bouckenooghe T, Reusens B \& Remacle C 2009 Early low protein diet aggravates unbalance between antioxidant enzymes leading to islet dysfunction. PLoS ONE 4 e6110.

Thureen PJ, Trembler KA, Meschia G, Makowski EL \& Wilkening RB 1992 Placental glucose transport in heat-induced fetal growth retardation. American Journal of Physiology 263 R578-R585.

Van Assche FA, De Prins F, Aerts L \& Verjans M 1977 The endocrine pancreas in small-for-dates infants. British Journal of Obstetrics and Gynaecology 84 751-753.

Veening MA, Van Weissenbruch MM, Heine RJ \& Delemarre-Van De Waal HA $2003 \beta$-Cell capacity and insulin sensitivity in prepubertal children born small for gestational age: influence of body size during childhood. Diabetes 52 1756-1760.

de Vrijer B, Regnault TR, Wilkening RB, Meschia G \& Battaglia FC 2004 Placental uptake and transport of ACP, a neutral nonmetabolizable amino acid, in an ovine model of fetal growth restriction. American Journal of Physiology. Endocrinology and Metabolism 287 E1114-E1124.

Wang J, Cortina G, Wu SV, Tran R, Cho JH, Tsai MJ, Bailey TJ, Jamrich M, Ament ME, Treem WR et al. 2006 Mutant neurogenin-3 in congenital malabsorptive diarrhea. New England Journal of Medicine 355 270-280.

Wang X, Cui Y, Tong X, Ye H \& Li S 2007 Glucose and lipid metabolism in small-for-gestational-age infants at 72 hours of age. Journal of Clinical Endocrinology and Metabolism 92 681-684.

Ward WK, Bolgiano DC, McKnight B, Halter JB \& Porte D Jr 1984 Diminished B cell secretory capacity in patients with noninsulin-dependent diabetes mellitus. Journal of Clinical Investigation 74 1318-1328.

Weir GC 1993a A defective $\beta$-cell glucose sensor as a cause of diabetes. New England Journal of Medicine 328 729-731.

Weir GC $1993 b$ The relationship of diabetes, loss of glucose-induced insulin secretion, and GLUT2. Journal of Diabetes and its Complications 7 124-129.

Wessells NK \& Cohen JH 1967 Early pancreas organogenesis: morphogenesis, tissue interactions, and mass effects. Developmental Biology 15 237-270.

Wigglesworth JS 1964 Experimental growth retardation in the foetal rat. Journal of Pathology and Bacteriology 88 1-13.

Received in final form 5 March 2010

Accepted 11 March 2010

Made available online as an Accepted Preprint 11 March 2010 